\title{
Chemometric Optimization of the Methodology for Determination of Molybdenum in Soils and Plants by Square Wave Adsorptive Stripping Voltammetry
}

\author{
José Ricardo de Carvalho, ${ }^{a}$ Efraim Lázaro Reis, ${ }^{\oplus a}$ César Reis, ${ }^{a}$ \\ Odilaine I. C. Damasceno, ${ }^{b}$ Antônio Augusto Neves ${ }^{\circledR} *, a$ and \\ Alexsandro Antônio Matias ${ }^{a}$
}

${ }^{a}$ Departamento de Química, Centro de Ciências Exatas e Tecnológicas, Universidade Federal de Viçosa, 36570-900 Viçosa-MG, Brazil

${ }^{b}$ Colégio de Aplicação, Universidade Federal de Viçosa, 36570-900 Viçosa-MG, Brazil

\begin{abstract}
The method is based on the adsorptive accumulation of complex molybdenum(VI) with 8-hydroxyquinoline, using voltammetric square wave cathodic stripping voltammetry. The composition and concentration of the supporting electrolyte, frequency $(\mathrm{Hz})$, amplitude $(\mathrm{mV})$ and deposition time (s), were optimized by factorial design in relation to current reduction of molybdenum(VI). The optimum methodology provided the following values for the process variables: scan increase $(0.5 \mathrm{mV})$, pulse amplitude $(127 \mathrm{mV})$, frequency $(96 \mathrm{~Hz})$, adsorption time $(80 \mathrm{~s})$ and drop size $\left(0.60 \mathrm{~mm}^{2}\right)$, the concentration of $\mathrm{KNO}_{3}\left(2.0 \mathrm{~mol} \mathrm{~L}^{-1}\right)$, acetate buffer $\left(0.5 \mathrm{~mol} \mathrm{~L}^{-1}\right)$ and 8-hydroxyquinoline $\left(0.01 \mathrm{~mol} \mathrm{~L}^{-1}\right)$. The results obtained after optimization showed a linear response in the range from 1.0 to $6.0 \mathrm{mg} \mathrm{L}^{-1}$ and limits of detection and quantification, respectively equal to 0.02 and $0.08 \mathrm{mg} \mathrm{L}^{-1}$. The molybdenum contained in the samples were determined using the optimized methodology, with values consistent with the values determined by atomic emission spectrometry with inductively coupled plasma (ICP-AES).
\end{abstract}

Keywords: molybdenum, redissolution voltammetry, 8-hydroxyquinoline, optimization

\section{Introduction}

Molybdenum is an essential trace element to living things and can be found practically in every biosphere. In the biological nitrogen fixation process, molybdenum is an essential micronutrient, whose functions in plants are related to the electron transfer system for nitrate reduction.

The lack of this element in the soil, in which the adequate concentration should be between 0.01 and $0.70 \mathrm{mg} \mathrm{kg}{ }^{-1}$, entails less synthesis of the nitrogenase enzyme in the plants, reducing the biological fixation of the nitrogen, ${ }^{1}$ consequently, making the soil less productive.

The concentration levels found in several matrices are very low, which makes monitoring and detection difficult. Thus, it is necessary to establish appropriate high sensitivity and selectivity methodologies for the determination of this element in complex matrices such as soils and plants. ${ }^{2,3}$

Atomic absorption spectrometry (AAS) has been one

*e-mail: aneves@ufv.br of the most suitable analytical methods in the literature for the determination of molybdenum. ${ }^{4,5}$ This technique is recommended for high sensitivity, low detection limit and high analytical quality, but a disadvantage is the high cost. Due to this issue, it is important to develop and improve techniques and methods of analysis that allow the direct quantification of molybdenum(VI) in several types of matrices, such as square wave voltammetry. ${ }^{6,7}$

Among the voltammetric methods, voltammetric redissolution techniques can be used, which can be carried out in three ways: anodic, cathodic and adsorptive, being that the adsorptive is the one that best adapts to the determinations for elements that are presented in low levels, in different matrices, being already used for determinations of vitamin $\mathrm{K} 1$ in foods, ${ }^{8,9}$ fungicides such as fenaxanil ${ }^{10}$ and $\mathrm{Mo}^{\mathrm{VI}}$ in water samples. ${ }^{11}$ Adsorptive cathodic stripping voltammetry (AdCSV) $)^{3,12-15}$ is a method that detects an electrochemically active complex formed by the reaction of the metal and a binder added to the sample. It consists of the accumulation of the analyte in the form of a suitable complex that is adsorbed on the surface of the electrode 
and subsequent, redissolution of the adsorptive material by cathodic scan of the potential.

The use of chemometric tools, such as factorial design ${ }^{16}$ and response surface methodology, ${ }^{17,18}$ made it possible to develop an optimized analytical methodology for the determination of $\mathrm{Mo}^{\mathrm{VI}}$ in soils and plants, using the square wave voltammetric technique with adsorptive cathodic stripping.

The optimization of voltammetric parameters ${ }^{19,20}$ for the determination of trace metals in soils and plants by means of redissolution techniques was planned in this work, considering factors such as equipment cost, sensitivity, selectivity and low detection limit.

The method proposed in this work is based on the adsorptive accumulation of molybdenum in the form of the complex with 8-hydroxyquinoline ${ }^{21,22}$ and subsequent electrochemical reduction of the complexed $\mathrm{Mo}^{\mathrm{VI}}$ in acidic medium. This proposed procedure is very sensitive for the determination in ultra trace levels and free of interferents, therefore presenting advantages in relation to other techniques being suitable for determinations in routine conditions.

\section{Experimental}

\section{Voltammetric equipment}

The experiments were conducted on a Metrohm ${ }^{\circledR}$ voltammetric analyzer, model 797 VA Computrace, using square wave voltammetry, operating with three electrode systems: a hanging mercury dropping electrode (HMDE) as the working electrode; an $\mathrm{Ag} / \mathrm{AgCl}$ electrode (saturated $\mathrm{KCl}$ ) as the reference electrode and a platinum electrode as the auxiliary electrode. Instrumental control and data acquisition were performed using VA Computrace 1.2 software.

\section{Reagents and solutions}

All the chemical reagents used were of analytical grade and did not undergo previous purification steps. Ultrapure deionized water was used for the preparation of all solutions.

The standard stock solution of $1.0 \mathrm{~g} \mathrm{~L}^{-1} \mathrm{Mo}^{\mathrm{VI}}$ was prepared from $\mathrm{Na}_{2} \mathrm{MoO}_{4} \cdot 2 \mathrm{H}_{2} \mathrm{O}$ in $0.1 \mathrm{~mol} \mathrm{~L}^{-1} \mathrm{HNO}_{3}$. Diluted standards were prepared from the stock solution.

The stock solution of $0.1 \mathrm{~mol} \mathrm{~L}^{-1}$ 8-hydroxyquinoline (Vetec) was prepared in $0.5 \mathrm{~mol} \mathrm{\textrm {L } ^ { - 1 }} \mathrm{HCl}$ (Merck). By dilution, a $0.01 \mathrm{~mol} \mathrm{~L}^{-1}$ solution of 8-hydroxyquinoline was obtained, while the $3.0 \mathrm{~mol} \mathrm{~L}-1$ solution of $\mathrm{KNO}_{3}$ (Vetec) was prepared in deionized water. The $2.0 \mathrm{~mol} \mathrm{~L}^{-1}$ acetate buffer solution was prepared with $\mathrm{CH}_{3} \mathrm{COOH}$ (Merck) and $\mathrm{CH}_{3} \mathrm{COOHNa}$ (Vetec) and had the $\mathrm{pH}$ set at 4.65 .

\section{Preparation of the sample}

To validate the developed voltammetric methodology, soil and plant material samples were obtained from the sample bank of Soils Department of the Federal University of Viçosa (MG-Brazil). Mass of $0.25 \mathrm{~g}$ of dry soil samples were digested with total attack of four acids $\left(\mathrm{HNO}_{3}, \mathrm{HClO}_{4}, \mathrm{H}_{2} \mathrm{SO}_{4}\right.$ and $\mathrm{HF}$ ) and of vegetal material with $\mathrm{HNO}_{3}$ and $\mathrm{H}_{2} \mathrm{O}_{2}$ in a digester block. All procedures were performed in triplicate.

The digested was diluted to $50 \mathrm{~mL}$ in volumetric flask and $100 \mu \mathrm{L}$ aliquots were used in the $\mathrm{Mo}^{\mathrm{VI}}$ determination procedure.

\section{Optimization procedures}

Initial tests of all mixing and process variables

In order to identify the really significant mixtures (acetate buffer, $\mathrm{KNO}_{3}, 8$-hydroxyquinoline) and process variables (scan increment, voltage amplitude, frequency, adsorption time and mercury drop size) univariate preliminary tests were performed.

It was added $10 \mathrm{~mL}$ of deionized water in the voltammetric cell, $1.3 \mathrm{~mL}$ of acetate buffer solution, $2.0 \mathrm{~mL}$ of $\mathrm{KNO}_{3}$ and $70 \mu \mathrm{L}$ of the 8-hydroxyquinoline. The solution was purged with ultrapure $\mathrm{N}_{2}$ for $600 \mathrm{~s}$. The concentration of $\mathrm{Mo}^{\mathrm{VI}}$ was maintained at $2.95 \mu \mathrm{g} \mathrm{L}^{-1}$, by the addition of $200 \mu \mathrm{L}$ of $\mathrm{Mo}^{\mathrm{VI}}$ at $200 \mu \mathrm{g} \mathrm{L} \mathrm{L}^{-1}$.

After $10 \mathrm{~s}$ of equilibrium a voltammetric scan was made using the square wave voltammetric technique with adsorptive cathodic stripping, in the potential range of -0.25 to $-0.75 \mathrm{~V}$. The current peak of the $\mathrm{Mo}^{\mathrm{VI}}$ complex with 8-hydroxyquinoline occurs at approximately $-0.54 \mathrm{~V}$. The effects of the variables were obtained using the Statistica 7.0 software. ${ }^{23}$

Factorial design for the mixing variables (supporting electrolyte and complexant)

A factorial design $2^{3}$ was performed using the mixing variables (Table 1), keeping fixed the values of the process variables obtained from univariate preliminary tests.

Factorial design for process variables (voltammetric parameters)

A factorial design with five process variables was performed (Table 2), keeping fixed the values of the mixture variables obtained in the factorial $2^{3}$.

The variables chosen as a function of the $t$-test and the respective levels are shown in Table 3 in a central composite design (CCD) $2^{3}$.

The study of the variables of the technique provided by VA Computrace 1.2 software, such as amplitude $(\mathrm{mV})$, 
Table 1. Mixing variables and levels chosen for factorial design $2^{3}$

\begin{tabular}{lccc}
\hline \multirow{2}{*}{ Symbol } & Variable & \multicolumn{2}{c}{ Level } \\
\cline { 3 - 4 } & $\mathrm{KNO}_{3} /\left(\mathrm{mol} \mathrm{L}^{-1}\right)$ & 0.5 & + \\
\hline $\mathrm{CK}$ & acetate buffer $/\left(\mathrm{mol} \mathrm{L}^{-1}\right)$ & 0.05 & 1.0 \\
$\mathrm{ST}$ & 8-hydroxyquinoline $/\left(\mathrm{mol} \mathrm{L}^{-1}\right)$ & 0.005 & 0.050 \\
$\mathrm{CO}$ & & &
\end{tabular}

Table 2. Process variables and levels chosen for factorial design $2^{5}$

\begin{tabular}{lccc}
\hline \multirow{2}{*}{ Symbol } & Variable & \multicolumn{2}{c}{ Level } \\
\cline { 3 - 4 } & scan increment / $\mathrm{mV}$ & 0.5 & 5 \\
\hline SI & amplitude / $\mathrm{mV}$ & 75 & 150 \\
AM & frequency / Hz & 50 & 125 \\
FR & adsorption time / s & 30 & 180 \\
AT & drop size / $\mathrm{mm}^{2}$ & 0.2 & 0.6 \\
DS & & &
\end{tabular}

Table 3. Process variables and levels chosen for CCD design

\begin{tabular}{lccccc}
\hline \multirow{2}{*}{ Variable } & -1.682 & -1 & 0 & +1 & +1.682 \\
\cline { 2 - 5 } & 76 & 90 & 110 & 130 & 144 \\
\hline $\mathrm{AM} / \mathrm{mV}$ & 46 & 60 & 80 & 100 & 114 \\
$\mathrm{FR} / \mathrm{Hz}$ & 63 & 70 & 80 & 90 & 97 \\
$\mathrm{AT} / \mathrm{s}$ & &
\end{tabular}

AM: amplitude; FR: frequency; AT: adsorption time.

frequency $(\mathrm{Hz})$ and adsorption time (s), were analyzed for the largest analytical signal as measured current.

\section{Analytical procedure}

In all subsequent analyzes the solutions in the voltammetric cell were prepared by adding the same volumes of the solutions of the initial design with the optimized concentrations and with the optimized process variables. To construct an analytical curve to verify the linearity of the responses, $\mathrm{Mo}^{\mathrm{VI}}$ was maintained in concentrations between 1.0 and $6.0 \mu \mathrm{g} \mathrm{\textrm {L } ^ { - 1 }}$.

The voltammetric analyzer was programmed to perform three scans in each experiment recording the average of the maximum peak currents in the molybdenum determination potential. Each assay was performed in triplicate.

\section{Sampling analysis}

With the optimized variables, $\mathrm{Mo}^{\mathrm{VI}}$ determinations were made in each sample, using $100 \mu \mathrm{L}$ of the sample solution and adding two aliquots of $100 \mu \mathrm{L}$ of the standard solution of $\mathrm{Mo}^{\mathrm{VI}}$ in the concentration of $100 \mu \mathrm{g} \mathrm{\textrm {L } ^ { - 1 }}$ containing the pre-established volumes of the other solutions. To validate the methodology, Mo ${ }^{\mathrm{VI}}$ determinations were done in triplicate by atomic emission spectrometry with inductively coupled plasma (ICP-AES).

\section{Results and Discussion}

Optimization

$\mathrm{Mo}^{\mathrm{VI}}$ was maintained at the concentration of $2.95 \mu \mathrm{g} \mathrm{\textrm {L } ^ { - 1 }}$ by the addition of $200 \mu \mathrm{L}$ of $\mathrm{Mo}^{\mathrm{VI}}$ at the concentration of $200 \mu \mathrm{g} \mathrm{L} \mathrm{L}^{-1}$ in the voltammetric cell, according to initial design conditions.

Sequentially, to execute the design of the mixture variables (Table 1), according to the univariate preliminary tests, the droplet size (DS) was set at its mean value $0.4 \mathrm{~mm}^{2}$, the frequency (FR) at $50 \mathrm{~Hz}$, the amplitude (AM) at $100 \mathrm{mV}$, the scan increment (SI) at $3 \mathrm{~s}$ and the adsorption time (AT) at $80 \mathrm{~s}$.

Using $\mathrm{KNO}_{3}$, acetate buffer, and 8-hydroxyquinoline complexing as mixing variables and levels chosen with Table 1, and according to the results presented in Table 4, the following optimized values were obtained for the variables: $\mathrm{KNO}_{3}(\mathrm{CK}) 2.0 \mathrm{~mol} \mathrm{~L}{ }^{-1}$, acetate buffer (ST) at $0.5 \mathrm{~mol} \mathrm{~L}^{-1}$ $(\mathrm{pH} 4.65)$ and 8-hydroxyquinoline (CO) $0.01 \mathrm{~mol} \mathrm{~L}^{-1}$.

It proceeded in sequence with the design experiments with the process variables (Table 2). According to the results presented in Table 5, all the main effects were significant showing that the chosen variables interfered positively in the voltammetric response at the levels studied.

Figure 1 shows the graphical representation of the significant second order interaction effects highlighted in Table 5. The interaction $(\mathrm{SI} \times \mathrm{AM})$ indicates that by

Table 4. Effects and errors for the mixture variables studied in the factorial design $2^{3}$

\begin{tabular}{lcc}
\hline Effects estimate $\pm{\text { standard } \text { error }^{\mathrm{a}}}^{2}$ & Relationship $\mathrm{t}(1)$ \\
\hline Average & $118.45 \pm 1.005$ & 117.86 \\
\hline CK & $-4.07 \pm 2.010^{\mathrm{b}}$ & -2.025 \\
ST & $84.21 \pm 2.010$ & 41.89 \\
CO & $61.79 \pm 2.010$ & 30.74 \\
\hline & $2^{\text {nd }}$ order interaction & \\
\hline CK $\times$ ST & $33.23 \pm 2.010$ & 16.53 \\
CK $\times$ CO & $7.52 \pm 2.010^{\mathrm{b}}$ & 3.74 \\
ST $\times$ CO & $141.39 \pm 2.010$ & 70.34 \\
\hline
\end{tabular}

aThe estimation of the standard errors was done with the third order effects; ${ }^{\mathrm{b}}$ only the main effect $\mathrm{CK}$ and the second order interaction $\mathrm{CK} \times \mathrm{CO}$ were not significant by the $t$-test $(\alpha=0.05)$. $\mathrm{CK}$ : $\mathrm{KNO}_{3}$; ST: acetate buffer; CO: 8-hydroxyquinoline. 
Table 5. Principal effects and second order interactions and significant errors by the $t$-test for the process variables studied in the factorial design $2^{5}$

\begin{tabular}{lcc}
\hline \multicolumn{3}{l}{ Effects estimate \pm standard error } \\
\hline Average & $412.83 \pm 16.95^{\mathrm{b}}$ & Relationship $\mathrm{t}(16)$ \\
\hline \multicolumn{3}{c}{ Main effects } \\
\hline SI & $161.39 \pm 33.89^{\mathrm{b}}$ & 4.76 \\
AM & $358.46 \pm 33.89^{\mathrm{b}}$ & 10.57 \\
FR & $134.80 \pm 33.89^{\mathrm{b}}$ & 3.98 \\
AT & $185.25 \pm 33.89^{\mathrm{b}}$ & 5.47 \\
DS & $123.23 \pm 33.89^{\mathrm{b}}$ & 3.64 \\
\hline & $2^{\text {nd }}$ order interaction \\
\hline SI $\times$ AM & $285.34 \pm 33.89^{\mathrm{b}}$ & \\
SI $\times$ FR & $-106.31 \pm 33.89^{\mathrm{b}}$ & -3.17 \\
AM $\times$ FR & $135.69 \pm 33.89^{\mathrm{b}}$ & 4.00 \\
AM $\times$ AT & $82.42 \pm 33.89^{\mathrm{b}}$ & 2.43 \\
AM $\times$ DS & $76.56 \pm 33.89^{\mathrm{b}}$ & 2.26 \\
FR $\times$ AT & $75.88 \pm 33.89^{\mathrm{b}}$ & 2.24 \\
\hline
\end{tabular}

aThe estimation of the standard errors was done with the high orders effects; ${ }^{\text {}}$ more significant interactions. SI: scan increment; AM: amplitude; FR: frequency; AT: adsorption time; DS: droplet size.

varying the levels of the voltage increase variable (SI) to the highest value within the negative level of the amplitude variable (AM), the mean response is minimal and that the same variation of scan increment variable (SI) levels within the positive amplitude variable (AM) level causes a significant increase in response producing a synergistic interaction effect SI $\times$ AM. This increase in response probably occurs due to the increase in the value of the applied pulse; consequently contributes to the abrupt electrode polarization and an effective exchange of electrons in the $\mathrm{Mo}^{\mathrm{VI}}$ complex with 8-hydroxyquinoline. While the interaction $(\mathrm{SI} \times \mathrm{FR})$ indicates that by varying the levels of the voltage increase variables (SI) to the highest value within the negative level of the frequency variable (FR) a positive change in the current response occurs, greater than the variation within the positive level of the frequency variable (FR), producing an antagonistic effect. The negative interaction SI $\times$ FR shows that increasing the frequency decreases the pulse time causing greater contribution of capacitive current.

The same rationale can be applied for the AM $\times$ FR, $\mathrm{AM} \times \mathrm{AT}, \mathrm{AM} \times \mathrm{DS}$ and $\mathrm{FR} \times \mathrm{AT}$ interactions, always observing synergistic effects. In an adsorption process the adsorption time plays an important role due to adsorption kinetics.

Amplitude (AM) was the statistically most important variable, both in the main effect, where it presented the highest value, and in the second order interactions (Table 5).

The droplet size variable (DS) was set at its maximum value $\left(0.6 \mathrm{~mm}^{2}\right)$ and the scan increment variable (SI) at its lowest level $(0.5 \mathrm{mV})$.

In this way a central composite design $(\mathrm{CCD}) 2^{3}$ was done, with the intention of investigating the more detailed influence of the amplitude (AM), frequency (FR) and adsorption time (AT) variables in the study method (Table 3). The results obtained from analysis of variance (ANOVA), showed that regression was significant, while the non-adjustment was not, which guarantees a second order model well adjusted for the proposed design.
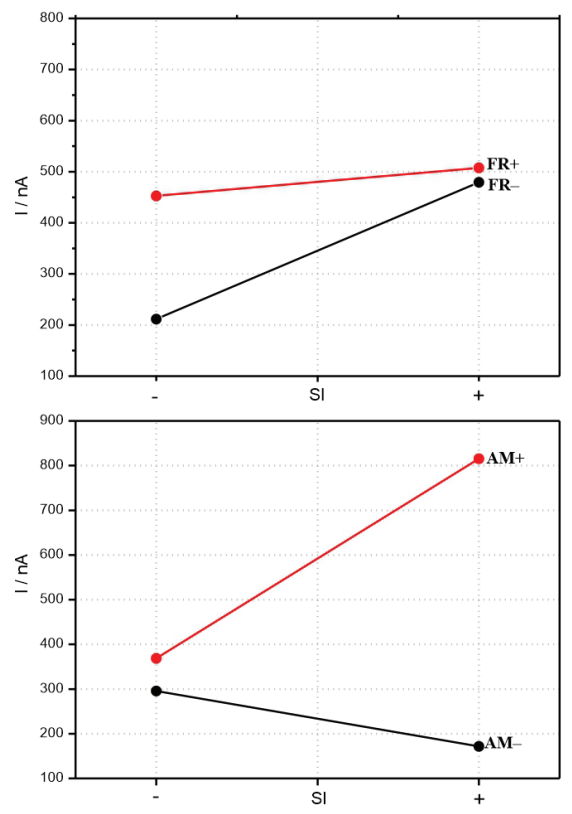
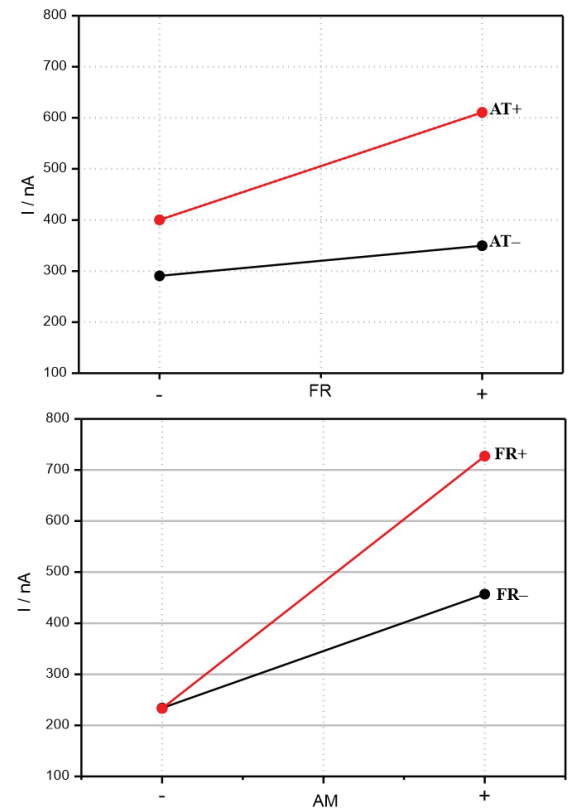
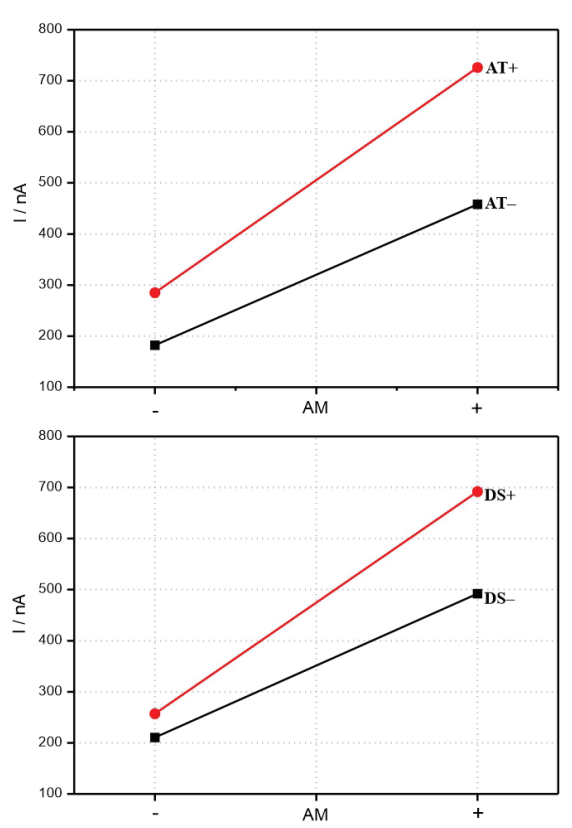

Figure 1. Graphs of second-order interaction effects of process variables. 

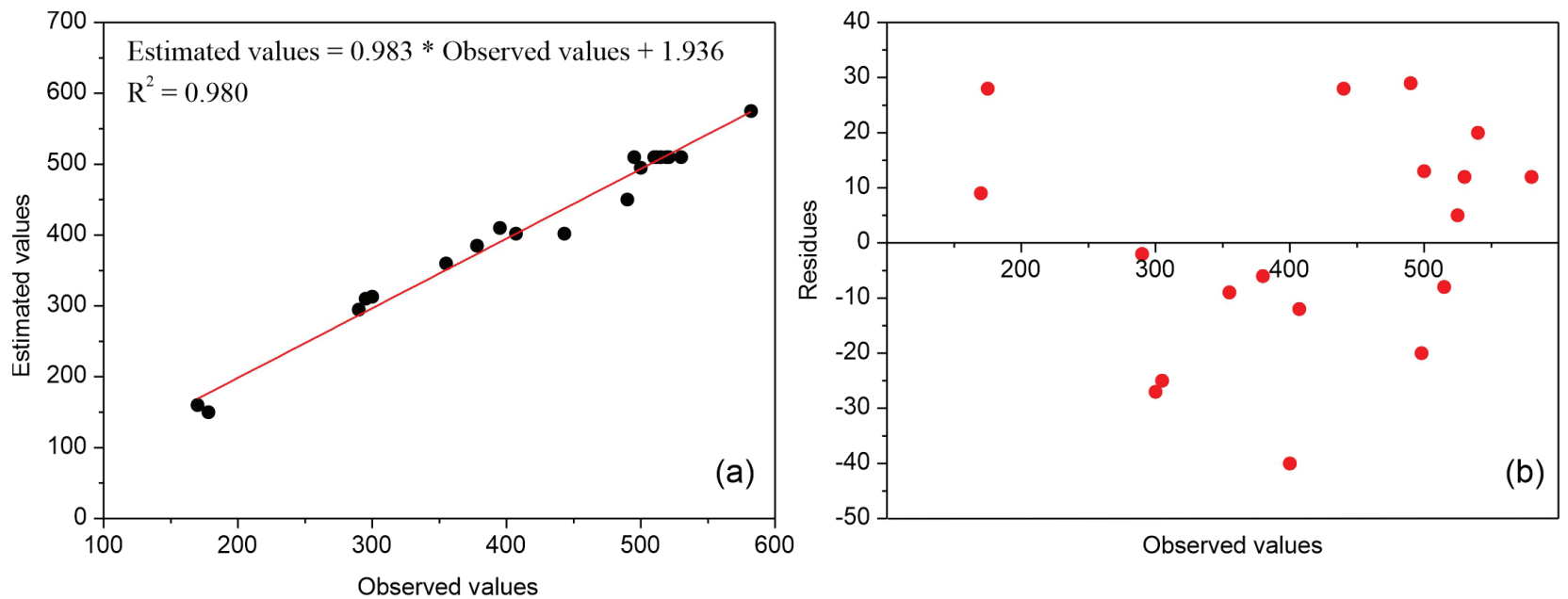

Figure 2. (a) Graphs of current values observed vs. estimated current values; (b) residual graph.

A graphical indication of the quality of the model can be visualized in Figures $2 a$ and $2 b$.

The quadratic model was evaluated by obtaining the adjusted equation for the significant coefficients and their respective errors according to the equation 1 presented.

$$
\begin{aligned}
& \mathrm{Z}=-8180.43+51.07(\mathrm{AM})+38.12(\mathrm{FR})-0.16(\mathrm{AM})^{2}- \\
& 0.09(\mathrm{FR})^{2}+99.48(\mathrm{AT})-0.39(\mathrm{AT})^{2}-0.13(\mathrm{AM} \times \mathrm{TA})- \\
& 0.26(\mathrm{FR} \times \mathrm{AT})
\end{aligned}
$$

According to the model obtained for square-wave voltammetry, the amplitude and frequency variables stand out as the two terms of greatest influence on the voltammetric response, being used in the response surface optimization, maintaining the adsorption time variables (AT) in the mean value $80 \mathrm{~s}$.

The optimization results (Figure 3) by response surface showed that the variables used in the design were appropriated by increasing the voltammetric response when they are used at the positive level, within the range under study. For the analyzed models, when adjusted at the highest level of the coded values on the response surface, the experimental current was practically the same predicted, showing that the model was well adjusted and that the variables did not interact at this level of study. The model constructed for the voltammetric determination of $\mathrm{Mo}^{\mathrm{VI}}$ is represented by the equation 2 .

$\mathrm{i}_{\mathrm{p}}=-2718.03+40.67 \mathrm{AM}-0.16(\mathrm{AM})^{2}+17.32 \mathrm{FR}-$

$$
0.09(\mathrm{FR})^{2}
$$

Table 6 presents the optimized variables, in addition to the initial and final potentials in the working conditions.

The optimized methodology for the determination of molybdenum using square wave voltammetry with

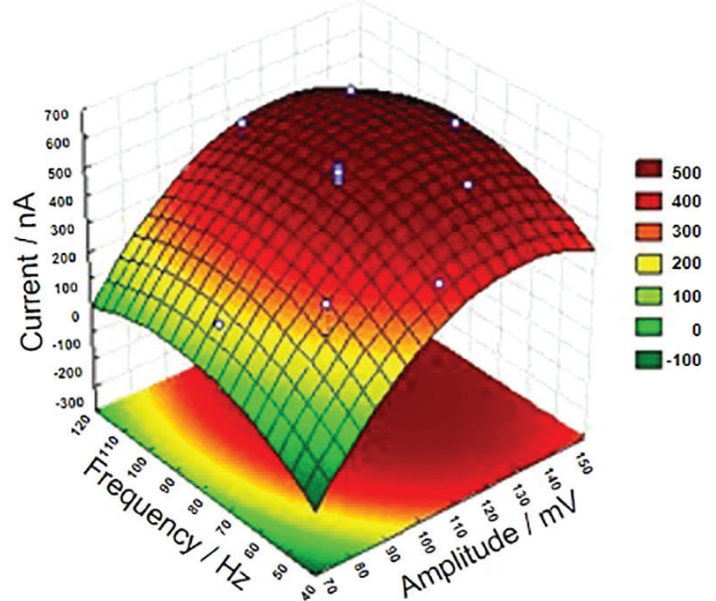

Figure 3. Response surface with variable adsorption time (AT) fixed at level (0), $80 \mathrm{~s}$. The legend shows the current values in $\mathrm{nA}$, obtained in the test. Concentration of $\mathrm{Mo}^{\mathrm{VI}}$ in the voltammetric cell equal to $2.95 \mu \mathrm{g} \mathrm{L}^{-1}$.

\begin{tabular}{|c|c|c|}
\hline Variable & Optimized value & Estimated current ${ }^{\mathrm{a}}$ \\
\hline $\mathrm{KNO}_{3} /\left(\mathrm{mol} \mathrm{L}^{-1}\right)$ & 2.0 & $523.89 \mathrm{nA}$ \\
\hline Acetate buffer / $\left(\mathrm{mol} \mathrm{L}^{-1}\right)$ & 0.5 & \\
\hline 8-Hydroxyquinoline / $\left(\mathrm{mol} \mathrm{L}^{-1}\right)$ & 0.01 & \\
\hline Initial potential / V & -0.25 & \\
\hline Final potential / V & -0.75 & observed current \\
\hline Scan increment / mV & 0.5 & $525.72 \mathrm{nA}$ \\
\hline Amplitude / mV & 127 & \\
\hline Frequency / Hz & 96 & \\
\hline Scan speed / $\left(\mathrm{mV} \mathrm{s}^{-1}\right)$ & 48.0 & \\
\hline Drop size $/ \mathrm{mm}^{2}$ & 0.60 & \\
\hline Adsorption time / s & 80 & \\
\hline
\end{tabular}

Table 6. Optimized analytical variables for molybdenum analysis by square wave voltammetry by adsorptive stripping. Concentration of $\mathrm{Mo}^{\mathrm{VI}}$ in the voltammetric cell equal to $2.95 \mu \mathrm{g} \mathrm{L} \mathrm{L}^{-1}$

aRelative error: $+0.34 \%$. 

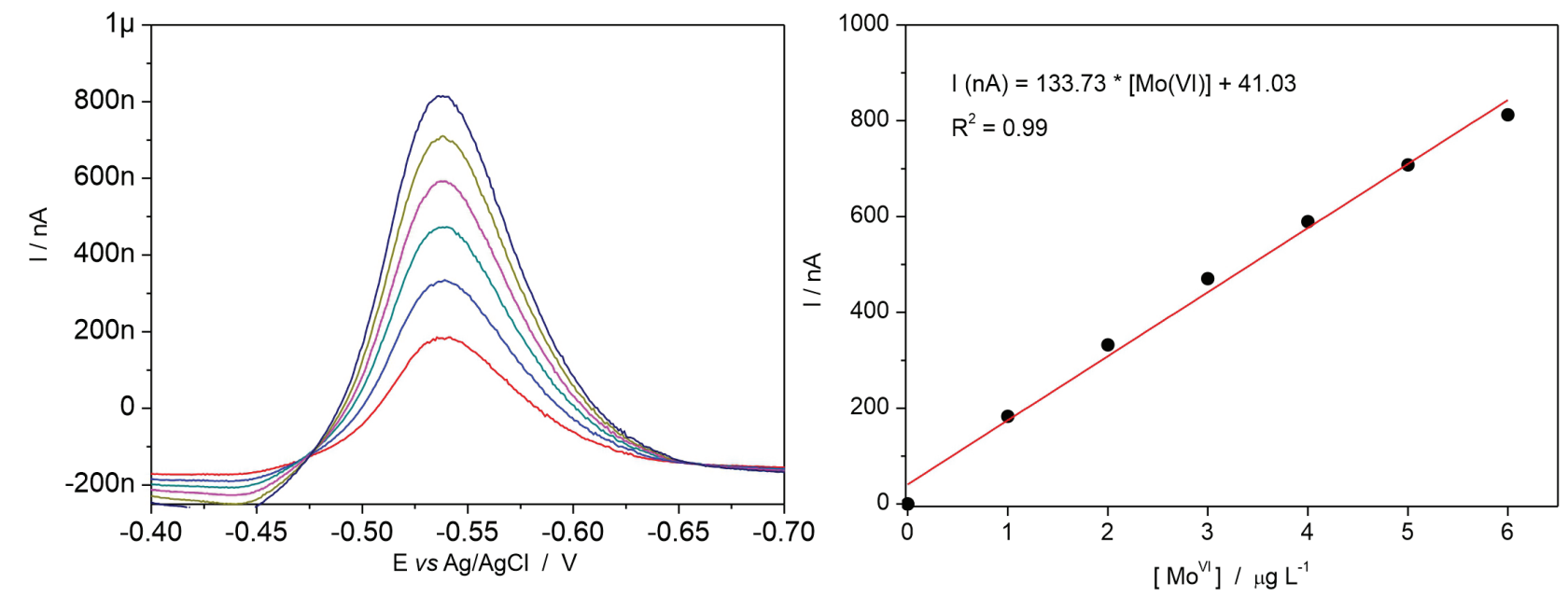

Figure 4. Voltamograms (a) and analytical curve (b) for the variation of the concentration of $\mathrm{Mo}^{\mathrm{VI}}$, in the range of 1.0 to $6.0 \mu \mathrm{g} \mathrm{L} \mathrm{L}^{-1}$.

adsorptive cathodic stripping showed a linear range of 1.0 to $6.0 \mu \mathrm{g} \mathrm{L} \mathrm{L}^{-1}$ (Figure 4).

Detection $\left(0.02 \mu \mathrm{g} \mathrm{L}^{-1}\right)$ and quantitation $\left(0.08 \mu \mathrm{g} \mathrm{L} \mathrm{L}^{-1}\right)$ limits were obtained using the standard deviation of the average of ten blank voltammograms measured currents at peak potential $(-0.54 \mathrm{~V})$.

The limit of detection was found by multiplying the standard deviation by three, dividing it by the angular coefficient of the analytical curve. To calculate the limit of quantification, the standard deviation was multiplied by ten and also divided by the angular coefficient of the analytical curve.

\section{Interfering}

Voltammetric scans were performed to better observe the interaction of the ions and their interference in the determination of $\mathrm{Mo}^{\mathrm{VI}}$ under optimized conditions and described for the method. In order to verify the interferences of the $\mathrm{Fe}^{3+}, \mathrm{Ca}^{2+}, \mathrm{Zn}^{2+}, \mathrm{Cd}^{2+}, \mathrm{Pb}^{2+}, \mathrm{Cu}^{2+}, \mathrm{Al}^{3+}, \mathrm{Ni}^{2+}, \mathrm{Cr}_{2} \mathrm{O}_{7}^{2-}$, $\mathrm{PO}_{4}{ }^{3-}, \mathrm{SO}_{4}{ }^{2-}$, these species were added in a 500 -fold higher concentration of $\mathrm{Mo}^{\mathrm{VI}}$ equal to $5.0 \mu \mathrm{g} \mathrm{\textrm {L } ^ { - 1 }}$ in the voltammetric cell.

High concentration ratios of these ions against $\mathrm{Mo}^{\mathrm{VI}} \mathrm{do}$ not affect the determination of molybdenum in the scanning range, and it is concluded that the method is resistant to interfering agents.

In this way, it was decided to apply and use the method in molybdenum determinations in soils and plants without the concern of micronutrient and macronutrient interferences and without the need of preconcentration or separation procedure.

Analytical application

The method developed was applied for the analysis of the samples, without any pretreatment or preconcentration, besides the opening by acid digestion, to determine $\mathrm{Mo}^{\mathrm{VI}}$ in plants by addition of standard, exemplified in Figure 5 .
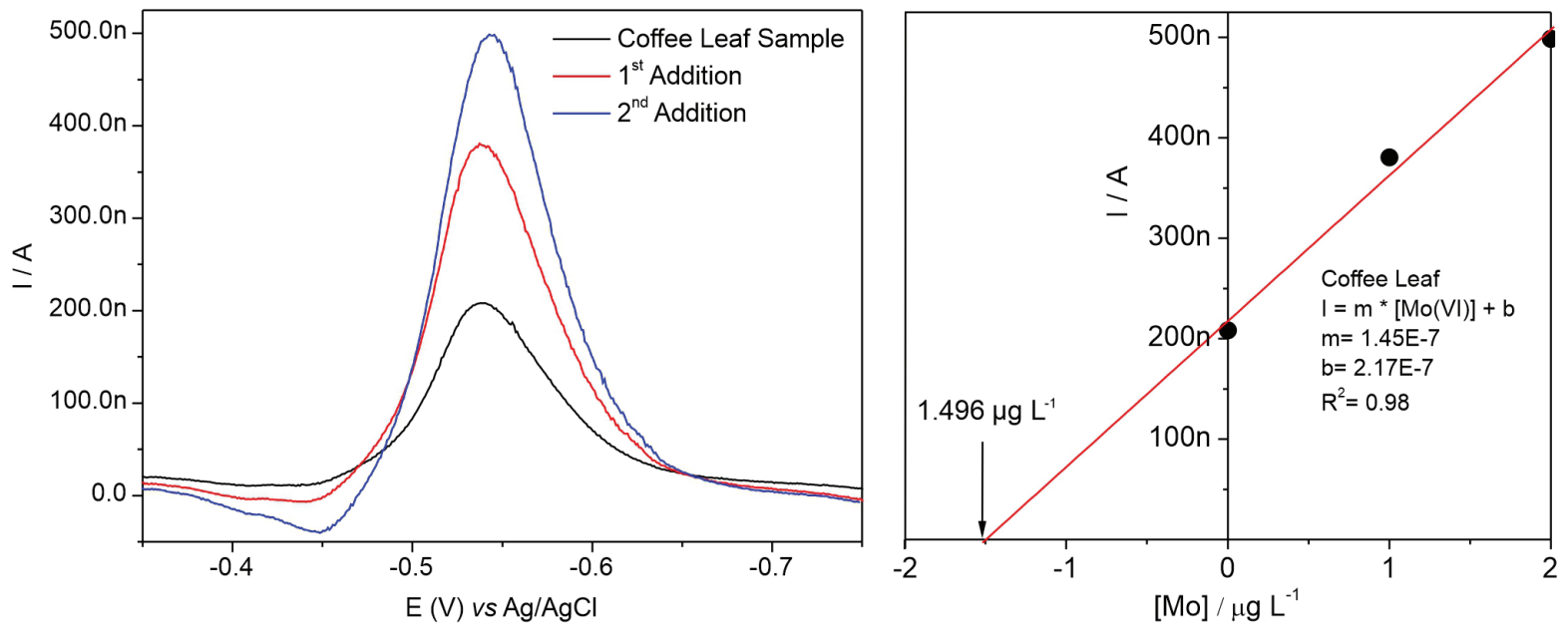

Figure 5. Standard addition analysis of the coffee leaf sample. 
The methodology optimized for the determination of $\mathrm{Mo}^{\mathrm{vI}}$ by square-wave voltammetry with adsorptive cathodic stripping in soils and plants, using the process and mixing variables optimized by the realized schedules, was efficient, fast and simple, presenting high sensitivity, with low limits of detection and quantification, allowing analysis at trace levels.

The comparison of the analytical results of the method described above with the results of the determination of molybdenum by atomic emission spectrometry with induced plasma source (ICP-AES) used as control method (Table 7), and the results reported in the literature, ${ }^{24-26}$ shows good agreement and indicates that the proposed method may be adequate for the determination of traces of molybdenum in soil and plant samples.

Table 7. Results of the determinations made by ICP-AES and the proposed voltammetric method for $\mathrm{Mo}^{\mathrm{VI}}$ in dry samples

\begin{tabular}{lcc}
\hline \multirow{2}{*}{ Sample } & \multicolumn{2}{c}{$\mathrm{Mo}^{\mathrm{IV}} /\left(\mathrm{mg} \mathrm{kg}^{-1}\right)$} \\
\cline { 2 - 3 } Banana leaf & Present method & ICP-AES \\
Coffee leaf & $3.067 \pm 0.083$ & $3.091 \pm 0.077$ \\
Chili leaf & $4.040 \pm 0.094$ & $4.051 \pm 0.101$ \\
Sugar cane leaf & $2.021 \pm 0.214$ & $2.259 \pm 0.205$ \\
Soil 1 & $\mathrm{ND}$ & $\mathrm{ND}$ \\
Soil 2 & $0.107 \pm 0.008$ & $0.120 \pm 0.011$ \\
Soil 3 & $0.358 \pm 0.080$ & $0.414 \pm 0.083$ \\
Soil 4 & $\mathrm{ND}$ & $\mathrm{ND}$ \\
\hline
\end{tabular}

ICP-AES: atomic emission spectrometry with inductively coupled plasma; ND: not detectable.

\section{Conclusions}

A methodology for the determination of molybdenum in samples of agronomic interest was developed and optimized.

The technique used was square wave adsorptive voltammetry with cathodic stripping. For this purpose, molybdenum(VI) was adsorbed as a complex with 8-hydroxyquinoline.

The mixture variables, electrolyte concentration, buffer concentration, and complexing agent concentration were studied by a factorial design $2^{3}$. While the process variables, scan increment, pulse amplitude, frequency, adsorption time and drop size were studied by design $2^{5}$. From the results of the factorial design a central composite design was done for the variables pulse amplitude, frequency and adsorption time.

The optimum methodology provided the following values for the process variables: scan increased $(0.5 \mathrm{mV})$, pulse amplitude $(127 \mathrm{mV})$, frequency $(96 \mathrm{~Hz})$, adsorption time $(80 \mathrm{~s})$ and drop size $\left(0.60 \mathrm{~mm}^{2}\right)$, the concentration of $\mathrm{KNO}_{3}\left(2.0 \mathrm{~mol} \mathrm{~L}^{-1}\right)$, acetate buffer $\left(0.5 \mathrm{~mol} \mathrm{~L}^{-1}\right)$ and 8-hydroxyquinoline $\left(0.01 \mathrm{~mol} \mathrm{~L}^{-1}\right)$.

The molybdenum contents contained in the banana, chili, sugar cane loafs and soil samples were determined using the optimized methodology, with values consistent with the values determined by ICP-AES.

\section{Acknowledgments}

The authors thank FAPEMIG for their financial support and CAPES for the master's degree grant to the first author (JRC).

\section{References}

1. Ensafi, A. A.; Khaloo, S. S.; Talanta 2005, 65, 788.

2. Andrade, J. C.; Almeida, A. M.; Aleixo, L. M.; Coscione, A. R.; Abreu, M. F.; Anal. Chim. Acta 2003, 487, 243.

3 Arabinda, K.; Chakraborty, R.; Cervera, M. L.; de la Guardia, M.; Talanta 2007, 71, 987.

4. Almeida, A. M.; Aleixo, L. M.; Andrade, J. C.; Coscione, A. R.; Quim. Nova 2006, 29, 153.

5. Pyzynska, K.; Anal. Chim. Acta 2007, 590, 40.

6. Souza, D.; Machado, S. A. S.; Avaca, L. A.; Pedrosa, V. A.; Codognato, L.; Malagutti, A. R.; Toledo, R. A.; Pedrosa, V. A. O.; Robson, T. S.; Mazo, L. H.; Quim. Nova 2004, 27, 790.

7. de Souza, D.; Galli, A.; Calegaro, M. L.; Machado, S. A. S.; Pires, R. C.; Quim. Nova 2007, 30, 458.

8. Sýs, M.; Jashari, G.; Svecová, B.; Arbneshi, T.; Metelka, R.; J. Electroanal. Chem. 2018, 821, 10.

9. Costa, D. J. E.; Martinez, A. M.; Ribeiro, W. F.; Bichinho, K. M.; di Nezio, M. S.; Pistonesi, M. F.; Araujo, M. C. U.; Talanta 2016, 154, 134.

10. Brycht, M.; Skrzypek, S.; Robak, J.; Guzsvány, V.; Vadjle, O.; Zbiljic, J.; Nosal-Wiercinska, A.; Guziejewski, D.; Andrijewski, G.; J. Electroanal. Chem. 2015, 738, 69.

11. Arancibia, V.; Rojas-Romo, C.; Aliaga, M. E.; Stegmann, E.; Sens. Actuators, B 2018, 258, 612.

12. Santos, L. B. O.; Masini, J. C.; Anal. Chim. Acta 2008, 606, 209.

13. Ensafi, A. A.; Khayamian, T.; Khaloo, S. S.; Int. J. Food Sci. Technol. 2008, 43, 416.

14. Jugade, R.; Joshi, A. P.; Acta Chim. Slov. 2005, 52, 145.

15. Ensafi, A. A.; Khayamian, T.; Khaloo, S. S.; Anal. Chim. Acta 2004, 505, 201.

16. Aouada, F. A.; de Moura, M. R.; Campese, G. M.; Girotto, E. M.; Rubira, A. F.; Muniz, E. C.; Polímeros 2008, 18, 126. 
17. Teófilo, R. F.; Reis, E. L.; Reis, C.; Silva, G. A.; Kubota, L. T.; J. Braz. Chem. Soc. 2004, 15, 865.

18. Teófilo, R. F.; Ferreira, M. M. C.; Quim. Nova 2006, 29, 338.

19. Neto, B. B.; Scarminio, I. S.; Bruns, R. E.; Como Fazer Experimentos: Pesquisa e Desenvolvimento na Ciência e na Indústria, $2^{\text {nd }}$ ed.; Editora da Unicamp: Campinas, Brazil, 2002.

20. Neto, B. B.; Scarminio, I. S.; Bruns, R. E.; Quim. Nova 2006, 29, 1401.

21. Navrátilová, Z.; Kopanica, M.; Anal. Chim. Acta 1991, 244, 193.
22. Sun, Y.; Mierzwa, J.; Chi-Ren, L.; Talanta 2000, 52, 417.

23. Statistica Software 7.0; StatSoft, Tulsa, OK, USA, 2007.

24. Baucells, M.; Lacort, G.; Roura, M.; Analyst 1985, 110, 1423.

25. Hoening, M.; Elsen, Y.; Cauter, R.; Anal. Chem. 1986, 58, 777.

26. Arambarri, R. G.; Millán, E.; Analyst 2000, 125, 2048.

Submitted: March 26, 2019

Published online: October 3, 2019 